\title{
BREEDING RECORDS OF THE GIANT CANADA GOOSE NEAR YORKTON, SASKATCHEWAN
}

\author{
by C. Stuart Houston, Saskatoon
}

In view of the paucity of nest records for the "Giant" Canada Goose (Branta canadensis maxima) in Saskatchewan evident in Harold C. Hanson's recent book, The Giant Canada Goose (see book review), I thought it might be of value to review my Yorkton records, presumably birds of this large subspecies or geographic race.

1. May 27, 1944. Pair with five downy goslings, Upper Rousay Lake.

2. May 14,1946 . Nest with six recently hatched eggs and one infertile egg in short grass three yards from water on low grassy island in Upper Rousay Lake. On July 13, two pairs of geese with a total of 14 goslings, presumably the products of the above nest and one other, were chased by canoe down the narrow southwest arm of Upper Rousay Lake by the

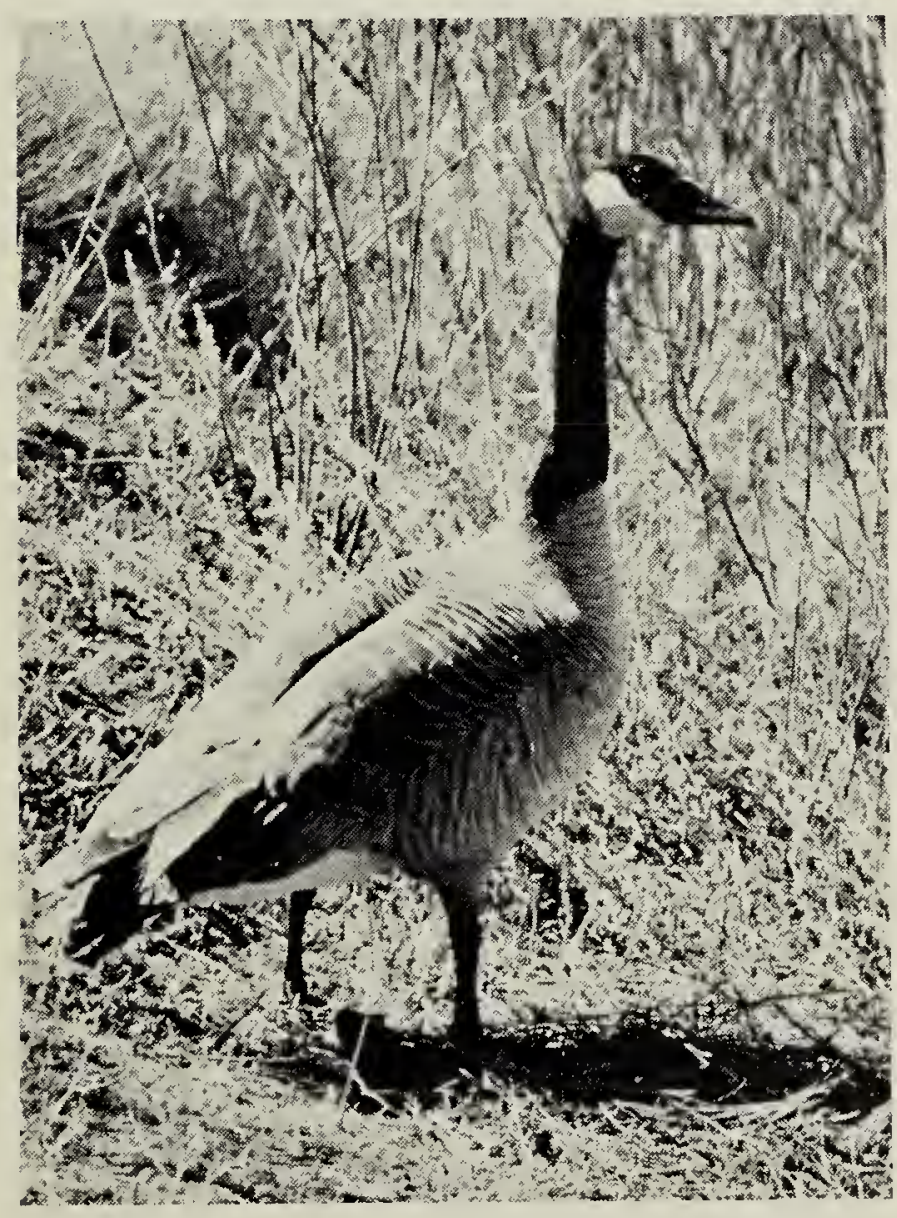

Photo by Fred W. Lahrman

Canada Goose, Wascana flock writer and Jimmy Allen. Little Bobby Bickel was crouched in the front of the canoe facing forwards and when one gosling separated and headed for the rushes I called out "Get the net ready!" Bobby blindly and excitedly put the net over the side just as the gosling reversed directions right into the net! The young goose was so heavy that it capsized the canoe; standing more than waist deep in water, it required the determined efforts of two of us to hold the struggling bird, while the other banded it. Two days later, on July 15, all the goslings were able to fly. The banded bird, 42-800852, was shot at Bredenbury, Sask., on October 15, 1947, by George R. Morrison, who reported that it weighed over 12 pounds (about 5.5 kilograms). This weight, attained at slightly over one year of age, refers it to the "Giant" Canada Goose.

3. May 15, 1946. John Domon, at the "Rokeby Marsh", six miles west and two miles north of Saltcoats, Sask., reported that at least four, and probably five, Canada Goose nests had hatching dates within two or three days of May 15.

4. June 22, 1947. Nest with six eggs, at Upper Rousay Lake. This is our latest date for a nest with eggs.

5. June 1 and 16, 1948. Nest with seven eggs, seven yards from water, on low flat grassy island in Lower Rousay Lake. On third visit, June 26, all seven eggs had hatched.

6. June 10, 1948. Nest with seven eggs on low flat grassy island in Upper Rousay Lake, 15 yards from water. When visited June 21, it was evident that at least five eggs had hatched successfully.

7. June 13, 1948. Nest with five eggs on very small bulrush island in 
"Rokeby Marsh", six miles west and two miles north of Saltcoats.

8. June 13, 1948. Pair with six goslings less than one week old on "Rokeby Marsh."

9. May 11, 1952. Nest with five eggs, Upper Rousay Lake.

10. May 10, 1954. Nest with six eggs at "Rokeby Marsh."

In 1946, observations of pairs present through the spring and early summer indicated that there were probably 12 breeding pairs in the Ducks Unlimited "Lake Illinois Project" south of Yorkton as follows: Upper Rousay Lake, two pairs; Lower Rousay Lake, one or two pairs; Leech Lake, two pairs; "Rokeby Marsh", four or five pairs.

Nesting was later in 1948 , when the spring was unusually delayed. The thaw began April 17, with the snow melting all at once. Bare ground was seen April 21. On April 22, a farmer, Fred Harris, said there hadn't been as much water in the country for 22 years. Water began running through the Ducks Unlimited ditch on April 24, and the level of Upper Rousay Lake rose two feet. There was still some ice in the lake on May 9. The new growth of grass did not appear in the meadows and sloughs until June 3 and 4 that year. Thus nesting probably began while there was still ice on the lake and the young could have hatched soon after the first green vegetation appeared.

It is likely that the numbers of Canada Geese in the Yorkton area have diminished in recent years as the water levels have fallen, but I have no observations to substantiate this.

Observations elsewhere in the province might be mentioned briefly. Gull banding expeditions to islands in Redberry Lake and the north end of Last Mountain Lake have disclosed successfully hatched Canada Goose nests at both locations. A pair with eight young were seen at Waterhen Marsh south of Kinistino on June 14, 1955 and a pair with at least five halfgrown young were seen at the same place Jüly 4, 1964. The greatest concentration I have seen was at the Quill Lakes, July 5, 1961 when over 20 flightless broods of geese were sighted from the air.

Editor's Note: In commenting on the status of the Canada Goose in northern Saskatchewan as reported in the Birds of the Lake Athabasca region, Hamilton M. Laing, Comox, B.C., who studied on Lake Athabasca in 1920, wrote as follows (pers. corres., 1963): "I was most interested in your findings re the geese. I can't go into details here but certainly you found more Canada Geese than were in the area we covered. The return of the Canada Goose is the brightest star in conservation's crown through the last 50 or 60 years. I began my gooseshooting career on Canadas in 1901 on the Rock Lake prairies in Manitoba, and I thought even then that their fate was sealed. In 1920 we saw only one breeding pair at the Chipewyan area [on Lake Athabasca in Alberta]; none were following the Mackenzie flyway and I'm quite sure that old Peter Lautit had shot few Canadas in his time (54 years when I met him in 1920). And now we have thousands of $B$. c. maxima to worry about! the goose check-listed as 'extinct' nearly or quite 50 years."

The Canada Goose of southwestern Saskatchewan has been identified as Branta canadensis moffiti, another large race (Caldwell, J. R. 1963. Some records of the Canada Goose breeding in southwestern Saskatchewan. Blue Jay 21:62-63). According to R. T. Sterling (1963. Wascana goose summers on the arctic prairie. Blue Jay, 21:134-135), this race also occasionally travels to the Arctic. Sterling also describes the recovery in the Arctic of a goose from the Regina flock, one which had been released on the South Saskatchewan River as a preflight young. The foregoing points out the problem of determining races of the Canada Goose by distribution alone, and the further complication resulting from attempts to establish geese across the prairie by introducing progeny from managed flocks. 